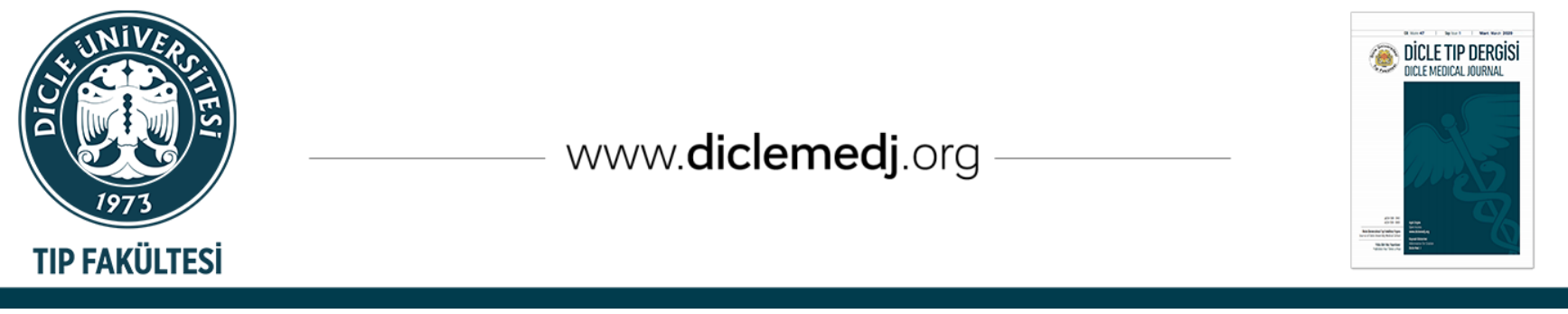

\title{
Akut Solunum Yolu Enfeksiyonu Olan Hastalarda Hızlı İnfluenza Tanı Testi ile İnfluenza A ve B Antijenlerinin Araştırılması
}

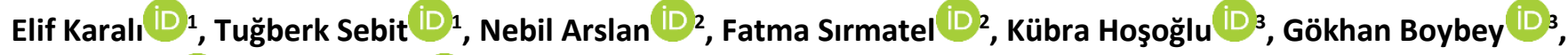 \\ Haluk Bulut ${ }^{\mathrm{D}} 3$, Önder Tokat ${ }^{\mathrm{D}} 3$
}

1 Bolu Abant İzzet Baysal Üniversitesi, Tıp Fakültesi, Kulak Burun Boğaz Baş ve Boyun Cerrahisi Anabilim Dalı Bolu, Türkiye

2 Bolu Abant İzzet Baysal Üniversitesi, Tıp Fakültesi, Enfeksiyon Hastalıkları Anabilim Dalı Bolu, Türkiye

3 Bolu Abant İzzet Baysal Üniversitesi, Tıp Fakültesi Intörn Bolu, Türkiye

Geliş: 26.10.2019; Revizyon: 24.03.2020; Kabul Tarihi: 24.03.2020

Öz

Amaç: $\mathrm{Bu}$ çalışmanın amacı, akut solunum yolu enfeksiyonu tanısı alan hastalarda hızlı influenza tanı testi ile nazofaringeal sürüntü örneklerinde influenza A ve B antijenlerinin sıklığının belirlenmesidir.

Yöntemler: Kasım 2018-Nisan 2019 tarihleri arasında hastanemiz Kulak Burun Boğaz Hastalıkları ve Enfeksiyon Hastalıkları polikliniğine ateş, boğaz ağrısı, öksürük, miyalji, burun akıntısı gibi şikayetlerle başvuran hastalar çalışma grubu olarak seçildi. Tek kollu kontrolsüz olarak yapılan bu çalışmada ateș, boğaz ağrısı, öksürük ve miyalji gibi üst solunum yolu enfeksiyonu semptomları olan hastalar değerlendirildi. Hastaların ağızları su ile 3 kez çalkalandıktan sonra nazofarengeal sürüntü örneklerinde hızlı influenza tanı testi Sağlı Bakanlığı aracılığı ile hastanemizde kullanılan kitler aracılı̆̆ ile yapıldı (Humasis Influenza A/B Antigen Test; Humasis, Anyang, Korea). Test prosedürüne uygun olarak poliklinik şartlarında yapılarak hastaların sürüntü materyellerinde İnfluenza A ve B antijeni araştırıldı.

Bulgular: Toplam 104 hasta çalışmaya alındı. Bu hastaların 68'i $(\% 65,4)$ kadın, 36'sı(\%34,6) erkek olup yaşları 18 ile 75 arasında (ortalama 36.13 ) değişmekteydi. Çalışma grubunda yer alan 104 hastanın 16 'sında $(\% 15,4)$ influenza hızlı tanı testi pozitifliği saptandı. Pozitif numunelerin tamamında influenza A tespit edildi. Boğaz ağrısı $(\% 87,5)$ en sık görülen klinik semptomdu. Hastalarda sırası ile burun akıntısı $(\% 80,76)$, miyalji $(\% 61,53)$ ve öksürük $(\% 60,57)$ şikâyeti olduğu görüldü. İnfluenza A pozitif olan hastalarda İnfluenza negatif olan hastalar ile karşılaştırıldığında öksürük varlı̆̆ı ve miyalji varlığı istatistiksel olarak anlamlı derecede yüksekti. $(p=0,003, p<0,001)$

DOI: 10.5798/dicletip.755738

Correspondence / Yazışma Adresi: Elif Karalı, Bolu Abant İzzet Baysal Üniversitesi, Tıp Fakültesi, Kulak Burun Boğaz Baş ve Boyun Cerrahisi Anabilim Dalı Bolu, Türkiye e-mail: elifkarali8181@gmail.com 
Sonuç: Öksürük ve miyalji varlığı diğer solunum yolu enfeksiyonu nedenlerinden influenzanın ayırt edilmesine yardımcı olabilir. Hastanemizde hızlı tanı testi ile influenza tespit oranı düşük olarak bulunmuştur. Ancak, influenza sezonunda özellikle risk grubundaki hastalarda hızlı ve kolay kullanımından dolayı bu test yararlı olabilir kanısındayız.

Anahtar kelimeler: İnfluenza A, İnfluenza B, hızlı antijen tanı testi

\title{
Investigation of Influenza A and B Antigens with Rapid Influenza Diagnosis Test in Patients with Acute Respiratory Tract Infection
}

\begin{abstract}
Objective: The aim of this study was to determine the frequency of influenza A and B antigens in the nasopharyngeal swab by rapid influenza diagnostic test in patients diagnosed with acute respiratory infection.

Method: The patients who applied to the Otorhinolaryngology and Infectious Diseases outpatient clinics between November 2018 and April 2019 with complaints such as fever, sore throat, cough, myalgia and runny nose were selected as the study group. In this singlearm uncontrolled study, patients with upper respiratory symptoms such as fever, sore throat, cough and myalgia were evaluated. After rinsing the mouth with water 3 times, the samples of nasopharyngeal swabs were performed with rapid influenza diagnostic test in the kits of the Ministry of Health (Humasis Influenza A/B Antigen Test; Humasis, Anyang, Korea). Influenza A and B antigens were investigated in swab materials of patients in accordance with the test procedure.
\end{abstract}

Results: A total of 104 patients were included in the study. 68 (65.4\%) of these patients were female and 36 (34.6\%) were male and their ages ranged between 18 and 75 (mean 36.13). Influenza rapid diagnostic test positivity was detected in 16 (15.4\%) of 104 patients in the study group. Influenza A was detected in all positive samples. Sore throat (87.5\%) was the most common clinical symptom. Nasal discharge $(80.76 \%)$, myalgia $(61.53 \%)$ and cough $(60.57 \%)$ were observed in the patients. Fourteen of the $16(81.3 \%)$ patients with influenza rapid diagnosis test had positive sore throat, cough, runny nose, myalgia symptoms, while the presence of cough and myalgia was significantly higher in influenza positive patients than in influenza negative patients. $(p=0,003, p<0,001)$.

Conclusion: The presence of cough and myalgia can help distinguish influenza from other causes of respiratory infections. The rate of influenza detection was low in our hospital with rapid diagnostic test. However, we believe that this test may be useful in patients at risk due to its rapid and easy use during influenza season.

Keywords: Influenza A, Influenza B, rapid antigen diagnostic test.

\section{GíRiş}

İnfluenza ani olarak başlayan ateş, kas ve eklem ağrıları, öksürük, boğaz ağrısı, burun akıntısı, aksırma gibi belirtilerin görüldüğü, insanlar arasında sezonu boyunca solunum yolu sekresyonları ile yayılan yüksek mortalite ve morbiditeye sahip bir hastalıktır. İnfluenzayı diğer solunum yolu enfeksiyonlarından ayırmak oldukça zordur. Mevsimsel grip virüsleri dünya çapında her yıl 3-5 milyon ağır enfeksiyona, 650000 ölüme neden olmaktadır ${ }^{1}$. Bununla birlikte mevsimsel influenza virüsleri çocuklar, kronik hastalığı olanlar, immun yetmezlikli hastalar ve gebelerde daha şiddetli ve ilerleyici seyreder ${ }^{2}$. Mevsimsel influenza için kullanılan antiviral ilaçların viral yükü azalttığı, viral çoğalma süresini kısalttı̆̆g, hastanede yatış süresini kısalttığı ve ölüm riskini azalttığı gösterilmiştir ${ }^{3}$. Bununla birlikte son yıllarda antiviral ajanlara karşı direnç geliştiği bildirildiğinden ilaçların endikasyon dahilinde kullanılması gerekmektedir ${ }^{4}$.

İnfluenza virüsü orthomyxoviridae ailesinin bir üyesidir ve insanda enfeksiyon yapan A, B, C olmak üzere 3 tipi vardır. A ve B salgınlara yol açarken, C sporodik hastalıklara neden olur. İnfluenza A antijenik duyarlılığa yüksek varyasyonu nedeniyle daha ciddi bir kliniğe neden olur ve daha yaygındır ${ }^{5}$. İnfluenza $\mathrm{A}$ virüsünün yüzeyindeki hemaglütinin ve nörpoaminidaz moleküllerinin niteliklerine göre farklı alt tipleri vardır ${ }^{5}$.

Özellikle risk gruplarındaki hastalarda influenza virüsünün hızlı ve doğru teşhisi epidemiyolojik verileri hızlı elde edilebilmesini ve uygun tedavinin yapılmasını sağlar6. 
İnfluenza virüs enfeksiyonlarının tanısında hızlı antijen testleri, hücre kültürü ve RT-PCR (Revers transkriptaz polimeraz zincir reaksiyonu) gibi çeşitli yöntemler kullanılmaktadır7. Bunlar arasında hücre kültürü ve RT-PCR altın standarttır7. Duyarlılığ yüksek olan hücre kültürü ve RT PCR gibi yöntemler pahalı ve zaman alıcı olduğundan poliklinik şartlarında kullanılamamaktadır. İnfluenza virüs enfeksiyonlarının tanısında, hızlı ve kolay olması nedeniyle hızlı antijen tanı testleri kullanılmaktadır. Ancak risk grubundaki şüpheli olgularda negatif sonuçlar alındığında tanıyı kesinleștirmek amacıyla RT PCR veya hücre kültürü gibi altın standart test yöntemlere başvurmak gerekmektedir. Hızlı tanı testleri solunum sekresyonlarında viral antijenlerin immünolojik olarak tespit edilmesi prensibi ile çalışırlar. Hızlı influenza antijen testlerinin dakikalar içinde sonuç vermeleri önemli bir avantajdır. Ancak bu testler influenza A ve influenza B arasında ayırım yapabilirken influenza A'nın alt tipleri hakkında bir fikir vermezler8. Yapılan çalışmalarda hızlı influenza testlerinin influenza A' nın tespitinde influenza $\mathrm{B}^{\prime}$ den daha hassas olduğu bildirilmiştir9 .

Hızlı antijen testlerinin hücre kültürü ve RT PCR ile karşılaştırıldığı çalışmalarda influenza hızlı antijen testlerinin duyarlılığ $\%$ 27-70, özgüllüğü ise \%95-100 aralığında verilmektedirler ${ }^{10-12}$. Bu geniş duyarlılık aralığı kullanılan kitin ve alınan örneğin türündeki farklılıklardan kaynaklanmaktadır. Bu testleri değerli kılan özgüllügünün yüksek olmasıdır. Nazofarengeal sürüntü örneklerinin tercih edilmesi duyarlılığı arttırmaktadır ${ }^{13}$. Çalışmada kullandığımız Humasis Influenza A/B Antigen Testinin influenza A için duyarlılı̆̆ı \%79,1 özgüllüğü \%100, influenza B için duyarlılığı \%41,8 özgüllüğü \%100 olarak raporlamıştır ${ }^{14}$.

$\mathrm{Bu}$ çalışmanın amacl, akut solunum yolu enfeksiyonu tanısı alan hastalarda hızlı influenza tanı testi ile nazofaringeal sürüntü örneklerinde influenza A ve B antijenlerinin sıklığının belirlenmesidir.

\section{YÖNTEMLER}

Kasım 2018-Nisan 2019 tarihleri arasında hastanemiz Kulak Burun Boğaz Hastalıkları ve Enfeksiyon Hastalıkları polikliniğine ateş, boğaz ağrısı, öksürük, miyalji ve burun akıntısı gibi şikâyetlerle başvuran 104 hasta çalışma grubu olarak seçildi. Tek kollu kontrolsüz olarak yapılan bu çalışmaya vücut sıcaklığının 37,8'den yüksek olduğu ateş ve miyalji, öksürük, boğaz ağrısı, burun akıntısı gibi sistemik ve solunumsal semptomlardan en az birinin olduğu hastalar dâhil edildi. Semptomların başlangıcından itibaren geçen sürenin 48 saatten fazla olduğu hastalar ve antiviral ilaç kullanmış olan hastalar çalışma dışında bırakıldı. Hastaların ağızları su ile $3 \mathrm{kez}$ çalkalandıktan sonra nazofarengeal sürüntü örneklerinde hızlı influenza tanı testi Sağlık Bakanlığı aracılığı ile hastanemizde kullanılan kitler aracılığı ile yapıldı (Humasis Influenza A/B Antigen Test; Humasis, Anyang, Korea). Hastalardan sürüntü çubuğuyla nazofarengeal sürüntü alınarak sürüntü çubuğu reaksiyon tüpünün içinde 10 sn. karıștırıldı. Sonra 6 damla numune alınarak test stribi üzerine eklendi. 8 dk. beklenerek okundu. Strip üzerindeki yukarıdaki kontrol çizgisinin altında bir çizgi daha oluşmuşsa test pozitif olarak kabul edildi.

Kriterlere uygun olan hastalar çalışmaya dahil edilmeden önce araştırma hakkında bilgilendirilerek onay alınması sonrası çalışmaya dahil edilmiştir. Bu çalışma Helsinki Deklarasyonu'na uygun olarak yapılmış ve kurumumuz klinik araştırmalar etik kurulundan 2018/220 karar numarası ile etik onayı alınmıştır.

\section{İstatistiksel Analizler}

Tanımlayıcı istatistik için sayısal değişkenlerde ortalama ve standart sapma, kategorik değişkenlerde ise sayı ve yüzde değerleri verilmiştir. Gruplar arasında fark olup olmadığ 
Mann Whitney u testi ile, kategorik değişkenler arasında ilişki olup olmadığı ise ki kare testi ile incelenmiştir. Anlamlılık düzeyi $\mathrm{p}<0,05$ olarak alınmıştır. Analizler IBM SPSS v.21 kullanılarak yapılmıştır.

\section{BULGULAR}

Toplam 104 hasta çalışmaya alındı. $\mathrm{Bu}$ hastaların $68(\% 65,4)^{\prime}$ i kadın, $36(\% 34,6)^{\prime}$ sı erkek olup yaşları 18 ile 75 arasında (ortalama 36.13 ) değişmekteydi. Çalışma grubunda yer alan 104 hastanın 16'sında $(\% 15,4)$ influenza hızlı tanı testi pozitifliği saptandı. Pozitif numunelerin tamaminda influenza A tespit edildi. Boğaz ağrısı $(\% 87,5)$ en sık görülen klinik semptomdu. Hastalarda sırası ile burun akıntısı $(\% 80,76)$, miyalji $(\% 61,53)$ ve öksürük $(\% 60,57)$ şikâyeti olduğu görüldü. (Tablo 1) İnfluenza negatif olan hastaların \%54,5 inde öksürük ve \%54,5'inde miyalji, pozitif olan hastaların ise \%93,8' inde öksürük ve tamamında miyalji olduğu görüldü.(tablo 2) İnfluenza A pozitif olan hastalarda İnfluenza negatif olan hastalar ile karşılaştırıldığında öksürük ve miyaljinin varlığı istatistiksel olarak anlamlı derecede yüksekti. ( $\mathrm{p}=0,003, \mathrm{p}<0,001$ Tablo 2).

Tablo I: Hastaların başvuru semptomları

\begin{tabular}{|c|c|c|c|}
\hline Semptom & & Hasta sayısı(n) & $\%$ \\
\hline & Yok & 12 & 11,7 \\
\hline \multicolumn{4}{|c|}{ Boğaz Ağrısı } \\
\hline & Var & 92 & 88,3 \\
\hline & Yok & 41 & 39,4 \\
\hline \multicolumn{4}{|l|}{ Öksürük } \\
\hline & Var & 63 & 60,6 \\
\hline & Yok & 40 & 38,5 \\
\hline \multicolumn{4}{|l|}{ Miyalji } \\
\hline & Var & 64 & 61,4 \\
\hline & Yok & 20 & 19,2 \\
\hline \multicolumn{4}{|c|}{ Burun Akıntısı } \\
\hline & Var & 84 & 80,8 \\
\hline
\end{tabular}

Tablo II. Semptom ve bulguların İnfluenza pozitifliği ile ilişkisi

\begin{tabular}{|c|c|c|c|c|c|}
\hline \multicolumn{6}{|c|}{ Influenza } \\
\hline & & $\begin{array}{c}\text { İnfluenza } \\
(-)\end{array}$ & $\begin{array}{c}\text { İnfluenza (+ } \\
\text { ) }\end{array}$ & $\begin{array}{l}\text { Odds } \\
\text { Ratio }\end{array}$ & $\mathbf{p}$ \\
\hline \multirow{2}{*}{ Cinsiyet } & Kadın & $56(63.6)$ & $12(75.0)$ & & 0.37 \\
\hline & Erkek & $32(36.4)$ & $4(25.0)$ & & 9 \\
\hline Yaş & & $\begin{array}{l}30.5[18- \\
81]\end{array}$ & $27[19-64]$ & - & $\begin{array}{c}0.46 \\
5\end{array}$ \\
\hline \multirow[b]{2}{*}{ Boğaz Ağrısı } & Yok & $12(13.8)$ & $0(0.0)$ & & 0.20 \\
\hline & Var & 75 (86.2) & $16(100.0)$ & - & 5 \\
\hline \multirow[b]{2}{*}{ Öksürük } & Yok* & $40(45.5)$ & $1(6.2)$ & \multirow[b]{2}{*}{12.5} & 0.00 \\
\hline & Var & $48(54.5)$ & 15 (93.8) & & 3 \\
\hline \multirow[b]{2}{*}{ Miyalji } & Yok* & $40(45.5)$ & $0(0.0)$ & \multirow[b]{2}{*}{$27.56^{* *}$} & $<0.0$ \\
\hline & Var & $48(54.5)$ & $16(100.0)$ & & 01 \\
\hline Burun & Yok & $17(19.3)$ & $3(18.8)$ & & 0.95 \\
\hline Akıntısı & Var & 71 (80.7) & 13 (81.3) & & 8 \\
\hline
\end{tabular}

\section{TARTIŞMA}

Özellikle yüksek riskli hastalarda yüksek morbidite ve mortaliteye sahip olan influenza virüsünün erken tanısı epidemiyolojik verileri hızlı elde edilebilmek ve hastalığın tedavisinde gereksiz antibiyotik kullanımının önüne geçebilmek için çok önemlidir6.

Dünya sağlık örgütü 2018-2019 sezonuna influenza A virüsünün hâkim olduğunu bildirdi ${ }^{15}$. İnfluenzanın mevsimsel dağılımını araştıran bir çalışmada Temmuz-Ağustos aylarında enfeksiyonun çoğundan influenza B sorumluyken, Ocak-Şubat aylarında İnfluenza $\mathrm{A}^{\prime}$ nın daha baskın olduğu raporlandıำ. Bizim 
çalışmamızda da influenza hızlı tanı testi pozitif örneklerin tamamında influenza A tespit edildi. Ülkemiz verilerine bakıldığında influenza benzeri hastalık vakalarından alınan örneklerde 2018-2019 influenza sezonunda \%27,0 olarak influenza pozitif saptanmış olup \%83,9' unu influenza A (H3N2) virüsü, \%9,1' ini influenza A (H1N1) virüsü, \%6,4 'ünü influenza $B$ virüsü oluşturmuştur ${ }^{17}$. Bizim çalışmamızda influenza benzeri hastalık vakalarından alınan örneklerde influenza hızlı tanı testi ile \%15,4 olarak influenza pozitifliği saptandı.

Taşbakan ve ark.' ının çalışmasında klinik olarak influenza düşünülen 100 erişkin hastanın 28' inde hızlı tanı testi ile influenza saptanmış ve influenza pozitif hastalarda negatif olanlarla karşılaştırdıklarında semptomlar açısından farklılık görülmemiști18.

Berktaş ve ark. yaptıkları çalışmada influenza şüphesi olan 52 hastanın hızlı tanı testi ile 17 (\%33)' sinde influenza A tespit etti ${ }^{12}$.

Beckman ve ark. hızlı tanı testi ile \%10,8 influenza A, \%0,9 influenza B pozitif olarak tespit etti ve hızlı tanı testinin duyarlılığını $\% 85,7$ özgüllüğünü $\% 100$ olarak bildirdi ${ }^{19}$.

Ceyhan ve ark.20 2011 yılında yaptıkları çalışmada hastaların \%34,1 oranında influenza A pozitifliği, Yang ve ark. ${ }^{21}$ 2012-2013 yılında $\% 36,7$ oranında influenza pozitifliği, Başaranoğlu ve ark.22 2015-2016 influenza sezonunda \%11,3 oranında influenza pozitifliği, Şimşek ve ark. $^{23}$ 2017-2018 influenza sezonunda \%25,68 influenza A, \%13,66 influenza $B$ pozitifliği bildirilmiştir.

Oranlardaki bu değișikliklerin grip benzeri hastalıkların yıldan yıla gösterdiği farklılıklar, farklı teknikler ve farklı yaş gruplarından kaynaklandığını söyleyebiliriz.

İnfluenzanın semptomları spesifik olmadığından diğer solunum yolu enfeksiyonlarından klinik olarak ayrımı zordur. Yapılan çalıșmalarda ateș ve öksürük influenzada en sık bildirilen semptomlardır ${ }^{24-26}$. Woolpert ve ark.' 1 da yaptıkları çalışmada ateş, öksürük ve miyalji varlığını influenzanın belirleyici semptomları olarak bildirmiștir ${ }^{25}$. Büyük veri tabanlı çalışmaların dahil edildiği sistematik bir derlemede influenza mevsiminde ani başlangıçlı öksürük ve ateşi olan hastalarda yüksek influenza olasılığı olduğunu bildirilirken miyalji varlı̆̆ influenza pozitif hastalarda anlamlı bulunmadı ${ }^{27}$. Pedersen ve ark. ise acil servise başvuran hastalarda yaptıkları çalışmada miyaljinin \%92,7 oranında özgüllüğe sahip olduğunu bildirdi ${ }^{28}$. Bizim çalışmamızda da öksürük ve miyalji varlığı influenza pozitif gurupta istatistiksel olarak anlamlıydı.

Çalışmamızın kısıtlılığı influenza tanısının klinik bulgular ve hızlı tanı testi ile konulmuş olup tanının hücre kültürü ve RT PCR gibi testlerle desteklenmemiş olmasıdır.

Sonuç olarak, öksürük ve miyalji varlığı diğer solunum yolu enfeksiyonu nedenlerinden influenzanın ayırt edilmesine yardımcı olabilir. Hastanemizde hızlı tanı testi ile influenza tespit oranı düşük olarak bulunmuştur. Ancak, influenza sezonunda özellikle risk grubundaki hastalarda hızlı ve kolay kullanımından dolayı bu test yararlı olabilir kanısındayız.

Etik Kurul Kararı: $\mathrm{Bu}$ çalışma Helsinki Deklarasyonu'na uygun olarak yapilmış ve kurumumuz klinik araştırmalar etik kurulundan 2018/220 karar numarası ile etik onayı alınmıştır.

Çıkar Çatışması Beyanı: Yazarlar çıkar çatışması olmadığını bildirmişlerdir.

Finansal Destek: Bu çalışma her hangi bir fon tarafından desteklenmemiştir.

Declaration of Conflicting Interests: The authors declare that they have no conflict of interest.

Financial Disclosure: No financial support was received. 


\section{KAYNAKLAR}

1. Influenza (seasonal), World Health Organization, Geneva (2018) https://www.who.int/news-room/factsheets/detail/influenza (seasonal), Accessed 2nd Oct 2019.

2. Belongia EA, Irving SA, Waring SC, et al. Clinical characteristics and 30-day outcomes for influenza A 2009 (H1N1), 2008-2009 (H1N1), and 2007-2008 (H3N2) infections. JAMA - J Am Med Assoc. 2010; 304: 1091-8.

3. Lee $\mathrm{N}$, Chan PKS, Wong $\mathrm{CK}$, et al. Viral clearance and inflammatory response patterns in adults hospitalized for pandemic 2009 influenza $A(H 1 N 1)$ virus pneumonia. Antiviral Therapy. 2011; 16: 237-47.

4. Stephenson I, Democratis J, Lackenby A, et al. Neuraminidase inhibitor resistance after oseltamivir treatment of acute influenza $a$ and $b$ in children. Clin Infect Dis 2009; 48: 389-96.

5. Treanor JJ. Influenza (Including Avian Influenza and Swine). In: Bennett JE, Dolin R, Blaser MJ, eds. Mandell, Douglas, and Bennett's Principles and Practice of Infectious Diseases. 8th ed. Philadelphia, PA: Churchill Livingstone Elsevier, 2015: 2000-24.

6. Poon LLM, Chan KH, Smith GJ, et al. Molecular detection of a novel human influenza (H1N1) of pandemic potential by conventional and realtime quantitative RT-PCR assays. Clin Chem. 2009; 55: 1555-8.

7. Nam MH, Jang JW, Lee JH, et al. Clinical performance evaluation of the BD Veritor System Flu A + B assay. J Virol Methods. 2014; 204: 86- 90.

8. Ghebremedhin B, Engelmann I, König W, König B. Comparison of the performance of the rapid antigen detection actim Influenza A\&B test and RT-PCR in different respiratory specimens. J Med Microbiol. 2009; 365-70.
9. Chartrand C, Leeflang MMG, Minion J, Brewer $T$, Pai M. Accuracy of rapid influenza diagnostic tests: A meta-analysis. Annals of Internal Medicine. 2012.

10. Uyeki TM, Prasad R, Vukotich C, et al. Low sensitivity of rapid diagnostic test for influenza. Clin Infect Dis 2009; 48: e89-92.

11. Akturk H, Sutcu M, Badur S, et al. Evaluation of epidemiological and clinical features of influenza and other respiratory viruses. Türk Pediatr Arşivi. 2015; 50: 217-25.

12. Berktaş M, Çikman A, Yaman G, Güdücüoğlu H. Assessment of DirectigenTM EZ Flu A+B rapid antigen diagnostic test for pandemic influenza A (H1N1). Turkiye Klin J Med Sci. 2011; 31: 548-52.

13. Smit M, Beynon KA, Murdoch DR, Jennings LC. Comparison of the NOW Influenza A \& B, NOW Flu A, NOW Flu B, and Directigen Flu A+B assays, and immunofluorescence with viral culture for the detection of influenza A and B viruses. Diagn Microbiol Infect Dis. 2007; 57: 67-70

14. Cho CH, Woo MK, Kim JY, et al. Evaluation of five rapid diagnostic kits for influenza A/B virus. J Virol Methods [Internet]. 2013;187(1):51-6. Available from: http://dx.doi.org/10.1016/j.jviromet.2012.09. 003.

15. Segaloff H, Melidou A, Adlhoch C, et al. Cocirculation of influenza a(H1N1)pdm09 and influenza a(H3N2) viruses, world health organization (WHO) european region, october 2018 to february 2019. Eurosurveillance. 2019; 9: 24 .

16. Jha BK, Pandit R, Jha R, Manandhar K Das. Overview of seasonal influenza and recommended vaccine during the 2016/2017 season in Nepal. Heliyon. 2020; 29; 6: e03304.

17. Sağlık Bakanlı̆̆l, Halk Sağlığ Müdürlüğü, 2018-2019 Haftalık İnfluenza 
Raporları (https://grip.gov.tr/tr/haftalikinfluenza-raporu

18. Ifl M, Sipahi OR, Pullukçu H, Taflbakan MS. Poliklinik Hastalarında İnfluenza Hızlı Tanı Testi. 2006; 1: 10-2.

19. Beckmann C, Hirsch HH. Diagnostic performance of near-patient testing for influenza. J Clin Virol. 2015; 67: 43-46.

20. Ceyhan M, Karadag Öncel E, Badur S ve ark. 2010-2011 kış sezonunda görülen influenza virusu tipleri ve tedavide Oseltamivir'in etkinligi. J Pediatr Inf 2012; 6: 1-5.

21. Yang JH, Huang PY, Shie S Sen, et al. Diagnostic performance of the Sofia ${ }^{\circledR}$ influenza $A+B$ fluorescent immunoassay in adult outpatients in Northern Taiwan. J Med Virol. 2018; 90: 1010-8.

22. Başaranoğlu ST, Aykaç K, Gözmen 0, et al. Duration of viral analysis in laboratory in the seasonal influenza period. Cocuk Enfeksiyon Derg. 2017; 11: e143-7.

23. Şimşek AÇ, Akdoğan D. Evaluation of Sentinel Influenza Like Illness (ILI) Surveillance Between The 40th Week of The Ankara Province in 2017 and The 20th Week of 2018. Ankara Med J. 2019; 19: 298 - 306.
24. Monto AS, Gravenstein S, Elliott M, Colopy M, Schweinle J. Clinical signs and symptoms predicting influenza infection. Arch Intern Med. 2000; 160: 3243-7.

25. Woolpert $\mathrm{T}$, Brodine $\mathrm{S}$, Lemus $\mathrm{H}$, et al. Determination of clinical and demographic predictors of laboratory-confirmed influenza with subtype analysis. BMC Infect Dis. 2012; 12: 129.

26. Call SA, Vollenweider MA, Hornung CA, Simel DL, McKinney WP. Does this patient have influenza? Journal of the American Medical Association. 2005; 293: 987-97.

27. Ebell MH, Afonso A. A systematic review of clinical decision rules for the diagnosis of influenza. Annals of Family Medicine. 2011;9: 69-77.

28. Pedersen CJ, Quinn J V., Rogan DT, Yang S. Factors Associated With Influenza in an Emergency Department Setting. J Emerg Med. 2019; 56: 478-83. 